\title{
Comparison of Quantity and Quality of Soil Organic Carbon between Matured and Gap Areas in an Old-growth Beech Forest
}

\author{
Yasuo IIMURA*, Mitsuru HIROTA**, \\ Hideyuki IDA*** and Toshiyuki OHTSUKA*
}

[Received 16 November, 2012; Accepted 21 December, 2012]

\begin{abstract}
We performed this study to further understand the effect of canopy gap stands on surface soil carbon dynamics in cool-temperate deciduous broad-leaved old-growth forests. We investigated the annual aboveground litter production, soil organic matter content, and soil humic acids (soil organic matter) quality in several matured $(n=7)$ and gap $(n=3)$ areas (each area was $20 \mathrm{~m} \times 20 \mathrm{~m}$ ) in a Japanese old-growth beech forest. The annual fine litter (foliage) production from 2005 to 2011 in the matured area was totally higher than that in the gap area; however, those of annual coarse litter production were not so different. The gravimetric soil carbon content in the matured area was significantly higher than that in the gap. In addition, the $\mathrm{C}: \mathrm{N}$ ratios in the matured area were significantly higher than those in the gap. The estimated compositions of carbonyl $\mathrm{C}$ and aromatic $\mathrm{C}$ and those of $O$-alkyl $\mathrm{C}$ and alkyl $\mathrm{C}$ in total $\mathrm{C}$ of soil humic acids in the matured area were higher and lower, respectively, dependent on higher $A_{600} / C$ values, than their respective compositions in the gap area. Furthermore, the ratio of alkyl $\mathrm{C}$ to $O$-alkyl $\mathrm{C}$ in the matured area was significantly lower than those of the gap. Our data strongly suggests that, compared to the closed canopy stands, canopy gap stands in this study site can be a carbon source, which is particularly dependent on labile carbon dynamics.
\end{abstract}

Key words : canopy gap stands, carbon dynamics, closed canopy stands, old-growth forest, soil organic matter

\section{Introduction}

For ecosystem carbon uptake, it is assumed that biomass production is the highest in young and middle-aged stands but declines with forest age (Pregitzer and Euskirchen, 2004) and that long-term soil carbon sequestration is very low (Schlesinger, 1990). Both factors suggest that old-growth forests (e.g., more than 100 years) are close to being carbon neutral, i.e., neither storing nor losing carbon (Odum, 1969, 1985).
However, recent studies, for example, Luyssaert et al. (2008), have reported that, in forests between 15 and 800 years, net ecosystem productivity is usually positive. Contrary to the long-standing view that old-growth forests are carbon neutral, these results demonstrate that they can continue to accumulate carbon. In addition, Pregitzer and Euskirchen (2004) demonstrated that soil carbon increased with time across boreal, temperate, and tropical forest biomes, a finding that conflicts with the notion that soil carbon content usually varies

\footnotetext{
* River Basin Research Center, Gifu University, Gifu, 501-1193, Japan

** Faculty of Life and Environmental Sciences, University of Tsukuba, Tsukuba, 305-8577, Japan

*** Institute of Nature Education in Shiga Heights, Faculty of Education, Shinshu University, Nagano, 381-0401, Japan
} 
slightly over time. These recent findings suggest that soil carbon dynamics is one of the key factors that controls carbon balance in old-growth forests.

Soil carbon dynamics in old-growth forests remain poorly understood because, depending on the gap-mosaic dynamics, these forests present more complex, changing, and heterogeneous structures than younger forests (Suchanek et al., 2004; Messier et al., 2009). Canopy gap stands are prevalent and dynamic in old-growth forests and represent sources of spatial and temporal variability in old-growth ecosystems (Pastor and Broschart, 1990; Frelich et al., 1993; Scharenbroch and Bockheim, 2007). Therefore, to broaden our understanding of old-growth carbon dynamics, the impacts of canopy gap stands on ecological processes in old-growth forests must be studied (Scharenbroch and Bockheim, 2008). Most canopy gap stands studies address vegetation dynamics and other aboveground phenomena, e.g., plant community diversity and plant productivity (Collins and Pickett, 1987; Mladenoff, 1990; Riddoch et al., 1991; Poulson and Platt, 1996). Few studies have focused on belowground processes.

Based on solubility, soil organic matter (soil humic substances) is often categorized into three fractions: humic acid (alkali soluble and acid insoluble), fulvic acid (alkali soluble and acid soluble), and humin (alkali insoluble). In particular, humic acid is a major fraction of soil organic matter and plays a crucial role in carbon dynamics in surface mineral horizons (Stevenson, 1994). The skeleton of soil humic acids is composed of aromatic rings and aliphatic chains, based on numerous ${ }^{13} \mathrm{C}$ nuclear magnetic resonance (NMR) data (Wilson, 1987; Smernik et al., 2004; Mao et $a l ., 2007)$. The degree of darkness $\left(A_{600} / C\right.$ values; $A_{600}$ is the absorbance value at $600 \mathrm{~nm}$ and $C$ is the carbon concentration) of various types of humic acids often correlates strongly with ${ }^{13} \mathrm{C}$ NMR data (Four major carbon species: carbonyl C, $O$-alkyl C, aromatic C, and alkyl C). Therefore, it is possible to use $A_{600} / C$ to qualitatively estimate the quality of soil humic acids (Ikeya et al., 2004; Watanabe, 2007).

This study aims to further understand the effect

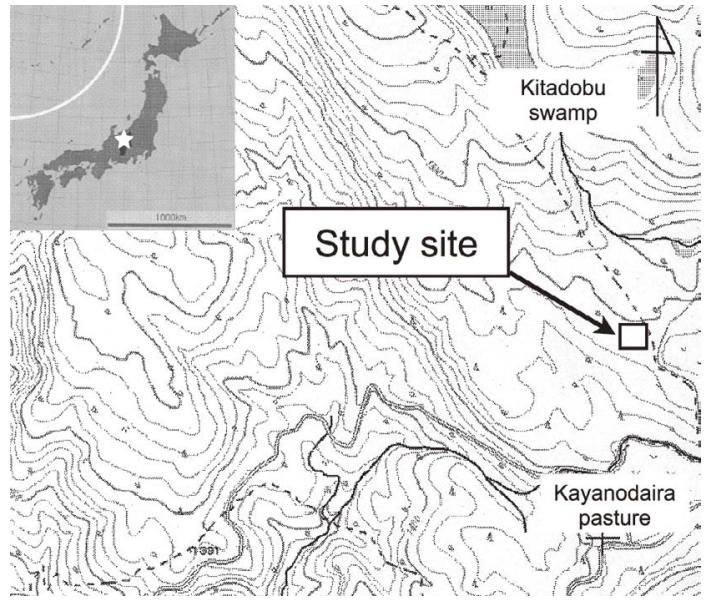

Fig. 1 Location of the Institute of Nature Education's Kayanodaira beech forest (KYD1) in Shiga highland at Shinshu University, Nagano Prefecture, Japan. Square indicates the permanent quadrat of $100 \mathrm{~m} \times 100 \mathrm{~m}$.

of the canopy gap stands on surface soil carbon dynamics in old-growth beech forest. We compared the aboveground litter production, soil carbon content, and the carbon quality of soil humic acids (soil organic matter) in surface mineral horizons between several closed canopy stands (matured area) and canopy gap stands (gap area) in a cooltemperate old-growth beech forest in Japan.

\section{Materials and methods}

\section{1) Site description}

The study site is located in the Institute of Nature Education's Kayanodaira beech forest in Shiga highland at Shinshu University, Nagano Prefecture, Japan (N 36 $50^{\prime} 19^{\prime \prime}$, E 138 30'1", 1495 m a.s.l.; Fig. 1). The mean annual precipitation is $1881 \mathrm{~mm}$, and the mean annual temperature is $10.5^{\circ} \mathrm{C}$ (1981-2010). The ground is covered by snow each year from November to the following May, and the snow depth is usually $3-4 \mathrm{~m}$. A permanent plot of 1 ha (KYD1) was established in 2005. This site is one of the Japanese Ministry of the Environment's "Monitoring Sites 1000" (Ishihara et al., 2011).

KYD1 is a cool-temperate deciduous broadleaved forest. The dominant species are Fagus crenata (83.6\% of basal area), Acer nipponicum 
Table 1 Species composition ( $\mathrm{DBH} \geq 5 \mathrm{~cm})$ in KYD1 site in 2010.

\begin{tabular}{|c|c|c|c|}
\hline \multirow[t]{2}{*}{ Species $(\mathrm{DBH} \geq 5 \mathrm{~cm})$} & \multirow{2}{*}{$\frac{\text { No. of stems }}{\mathrm{ha}^{-1}}$} & \multicolumn{2}{|l|}{ Basal area } \\
\hline & & $\mathrm{m}^{2} \mathrm{ha}^{-1}$ & $\%$ \\
\hline Fagus crenata & 258 & 27.4 & 83.6 \\
\hline Acer nipponicum & 197 & 0.89 & 2.71 \\
\hline Hydrangea paniculata & 127 & 0.41 & 1.24 \\
\hline Acer japonicum & 81 & 0.43 & 1.30 \\
\hline Viburnum furcatum & 81 & 0.23 & 0.70 \\
\hline Swida controversa & 61 & 0.16 & 0.50 \\
\hline Sorbus commixta & 37 & 0.17 & 0.53 \\
\hline Corylus sieboldiana & 29 & 0.07 & 0.21 \\
\hline Acanthopanax sciadophylloides & 23 & 0.41 & 1.24 \\
\hline Aesculus turbinata & 22 & 0.90 & 2.73 \\
\hline Euonymus macropterus & 21 & 0.08 & 0.25 \\
\hline Padus grayana & 18 & 0.08 & 0.26 \\
\hline Symplocos chinensis & 15 & 0.04 & 0.11 \\
\hline Acer rufinerve & 14 & 0.09 & 0.26 \\
\hline Phellodendron amurense & 10 & 0.15 & 0.46 \\
\hline Tilia japonica & 10 & 0.07 & 0.22 \\
\hline Betula ermannii & 5 & 1.11 & 3.37 \\
\hline Acer tschonoskii & 3 & 0.01 & 0.03 \\
\hline Rhus trichocarpa & 3 & 0.01 & 0.02 \\
\hline Acer mono var. mayrii & 1 & 0.09 & 0.28 \\
\hline Total & 1016 & 31.91 & 100.0 \\
\hline
\end{tabular}

(2.71\%), and Hydrangea paniculata (1.24\%) (Table 1). Tree census data for KYD1 was provided by the Ministry of the Environment Monitoring Sites 1000 Project $^{1)}$.

We selected several matured ( $n=7$, basal area: $\left.1.8-2.6 \mathrm{~m}^{2}\right)$ and gap areas $(n=3$, basal area: $\left.0.5-0.6 \mathrm{~m}^{2}\right)$ in each $20 \mathrm{~m} \times 20 \mathrm{~m}$ plot within the KYD1 based on basal area data from 2010 (Fig. $2)$. Both areas are composed of three dominant species (Fagus crenata, Acer nipponicum, and Hydrangea paniculata) more than $85.0 \%$ of basal area (Table 2).

2) Aboveground litter production and soil sampling

The aboveground litter production was estimated from litter traps $\left(0.5 \mathrm{~m}^{2}\right)$ in each matured and gap area $(20 \mathrm{~m} \times 20 \mathrm{~m})$ within the KYD1 site from 2005 to 2011 (Fig. 2). Each litter production data from 2005 to 2009 were provided by the Ministry of the Environment Monitoring Sites 1000 Project ${ }^{1)}$. Litterfall was separated into foliage (fine

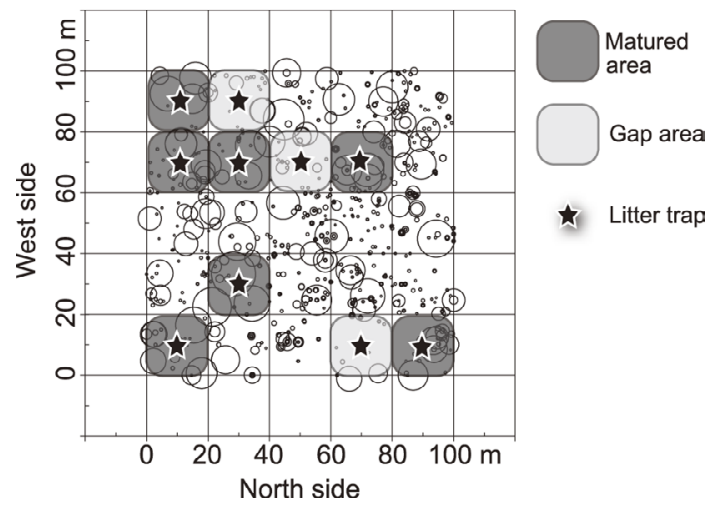

Fig. 2 Location of the matured and gap areas at the KYD1 site. Size of circles indicates the image of the canopy stands at the KYD1 site illustrated based on the DBH data from 2010. The matured (basal area: $1.8^{-}$ $2.6 \mathrm{~m}^{2} 0.04 \mathrm{ha}^{-1}$ ) and gap (basal area: $0.5^{-0} 0.6 \mathrm{~m}^{2}$ $0.04 \mathrm{ha}^{-1}$ ) areas were defined based on basal area data from 2010 . 
Table 2 Species composition $(\mathrm{DBH} \geq 5 \mathrm{~cm})$ in matured and gap areas in 2010 .

\begin{tabular}{|c|c|c|c|c|c|c|}
\hline \multirow{3}{*}{ Species $(\mathrm{DBH} \geq 5 \mathrm{~cm})$} & \multicolumn{3}{|c|}{ Matured $(n=7)$} & \multicolumn{3}{|l|}{ Gap $(n=3)$} \\
\hline & \multirow{2}{*}{$\frac{\text { No. of stems }}{\mathrm{ha}^{-1}}$} & \multicolumn{2}{|l|}{ Basal area } & \multirow{2}{*}{$\frac{\text { No. of stems }}{\mathrm{ha}^{-1}}$} & \multicolumn{2}{|l|}{ Basal area } \\
\hline & & $\mathrm{m}^{2} \mathrm{ha}^{-1}$ & $\%$ & & $\mathrm{~m}^{2} \mathrm{ha}^{-1}$ & $\%$ \\
\hline Fagus crenata & 304 & 37.4 & 87.0 & 117 & 12.8 & 75.2 \\
\hline Acer nipponicum & 150 & 0.65 & 1.50 & 233 & 1.25 & 7.35 \\
\hline Hydrangea paniculata & 125 & 0.40 & 0.93 & 183 & 0.57 & 3.34 \\
\hline Swida controversa & 96 & 0.26 & 0.60 & 8 & 0.02 & 0.11 \\
\hline Acer japonicum & 46 & 0.20 & 0.47 & 108 & 0.57 & 3.34 \\
\hline Viburnum furcatum & 32 & 0.09 & 0.20 & 42 & 0.13 & 0.77 \\
\hline Symplocos chinensis & 29 & 0.08 & 0.18 & 42 & 0.08 & 0.49 \\
\hline Acanthopanax sciadophylloides & 25 & 0.75 & 1.73 & 0 & & \\
\hline Euonymus macropterus & 25 & 0.09 & 0.22 & 8 & 0.02 & 0.10 \\
\hline Padus grayana & 18 & 0.08 & 0.19 & 33 & 0.14 & 0.80 \\
\hline Betula ermannii & 7 & 2.69 & 6.26 & 0 & & \\
\hline Phellodendron amurense & 4 & 0.16 & 0.37 & 8 & 0.32 & 1.86 \\
\hline Aesculus turbinata & 4 & 0.14 & 0.33 & 0 & & \\
\hline Corylus sieboldiana & 4 & 0.01 & 0.02 & 33 & 0.09 & 0.50 \\
\hline Acer rufinerve & & & & 58 & 0.27 & 1.57 \\
\hline Acer mono var. mayrii & & & & 8 & 0.78 & 4.57 \\
\hline Total & 868 & 43.01 & 100.0 & 883 & 16.99 & 100.0 \\
\hline
\end{tabular}

litter) and other woody material (coarse litter), oven-dried to a constant mass, and weighed.

Soil samples were collected in June 2010 from the surface mineral horizon $(0-10 \mathrm{~cm})$ of each mature forest plot and gap plot at five random spots and then mixed. They were then air-dried and passed through a 2-mm mesh sieve for laboratory analysis. This procedure was performed after thorough removal of plant debris and roots with tweezers under visual conditions.

\section{3) Laboratory analyses}

Gravimetric soil carbon and nitrogen contents were determined with a $\mathrm{CN}$-analyzer (Shimadzu NC-22F) with dry combustion method. Soil humic acid (main fraction of soil organic matter) samples were prepared according to the method of International Humic Substances Society (IHSS) ${ }^{2)}$ from each soil sample. The $A_{600} / C$ values of each humic acid were determined according to the methods used by Ikeya and Watanabe (2003). A larger $A_{600} / C$ values indicate a greater degree of humification (Ikeya and Watanabe, 2003). $A_{600}$ was measured using a UV-visible spectrophotom- eter (Thermo Scientific Evolition-201). C was measured using a total organic carbon analyzer (Shimadzu TOC-V $\mathrm{V}_{\mathrm{CSH}}$ ). Samples were prepared as follows. Humic acids were dissolved in $0.1 \mathrm{M}$ $\mathrm{NaOH}$ to determine the absorbance at $600 \mathrm{~nm}$. The solution was adjusted to approximately $\mathrm{pH}$ 4 by dilution $(5 \times)$ with $0.066 \mathrm{M} \mathrm{KH}_{2} \mathrm{PO}_{4}$, and dissolved $\mathrm{CO}_{2}$ was removed by bubbling with $\mathrm{N}_{2}$ to determine the organic $\mathrm{C}$ concentration. The composition of the four major $\mathrm{C}$ species in soil humic acids that appeared in the ${ }^{13} \mathrm{C}$ CPMAS NMR spectra (i.e., saturated alkyl C, alkyl C substituted with one or more hetero atoms $(O$-alkyl $\mathrm{C}$ ), aromatic C, and carbonyl C) was calculated from the significant correlations between $A_{600} / C$ values and the four major $\mathrm{C}$ species (Ikeya et al., 2004). The calculation was performed using the following equations:

$$
\begin{aligned}
& \text { Alkyl C }=-1.85 \times A_{600} / C+30.6, r=-0.569 \\
& \quad(P<0.05, n=18) \\
& O \text {-alkyl C }=-1.31 \times A_{600} / C+26.6, r=-0.715 \\
& \quad(P<0.005, n=18)
\end{aligned}
$$


Table 3 Annual aboveground detritus production $\left(\mathrm{t} \mathrm{C} \mathrm{ha}^{-1} \mathrm{yr}^{-1}\right)$ in the matured and gap areas. Different letters indicate significant difference $(P<0.05)$ between both areas.

\begin{tabular}{|c|c|c|c|c|c|c|c|c|}
\hline & $2005( \pm \mathrm{SD})$ & $2006( \pm \mathrm{SD})$ & $2007( \pm \mathrm{SD})$ & $2008( \pm \mathrm{SD})$ & $2009( \pm \mathrm{SD})$ & $2010( \pm \mathrm{SD})$ & $2011( \pm \mathrm{SD})$ & Average $( \pm \mathrm{SD})$ \\
\hline \multicolumn{9}{|l|}{ Fine litter } \\
\hline Matured $(n=7)$ & $2.37 \pm 0.41$ & $2.24 \pm 0.53$ & $2.90 \pm 0.25$ & $3.09 \pm 0.46$ & $3.34 \pm 0.77$ & $2.72 \pm 0.34$ & $2.85 \pm 0.22 \mathrm{a}$ & $2.79 \pm 0.39$ \\
\hline $\operatorname{Gap}(n=3)$ & $2.15 \pm 0.28$ & $2.14 \pm 0.37$ & $2.68 \pm 0.63$ & $2.68 \pm 0.51$ & $2.63 \pm 0.32$ & $3.05 \pm 0.54$ & $2.30 \pm 0.43 b$ & $2.52 \pm 0.33$ \\
\hline \multicolumn{9}{|l|}{ Coarse litter } \\
\hline Matured $(n=7)$ & $0.23 \pm 0.11$ & $0.48 \pm 0.72$ & $0.71 \pm 0.48$ & $1.50 \pm 1.00$ & $1.56 \pm 0.56$ & $1.12 \pm 0.41$ & $2.02 \pm 0.62$ & $1.09 \pm 0.65$ \\
\hline $\operatorname{Gap}(n=3)$ & $0.22 \pm 0.09$ & $0.40 \pm 0.09$ & $0.75 \pm 0.70$ & $1.12 \pm 0.44$ & $1.65 \pm 1.01$ & $1.24 \pm 0.61$ & $2.24 \pm 1.90$ & $1.09 \pm 0.71$ \\
\hline
\end{tabular}
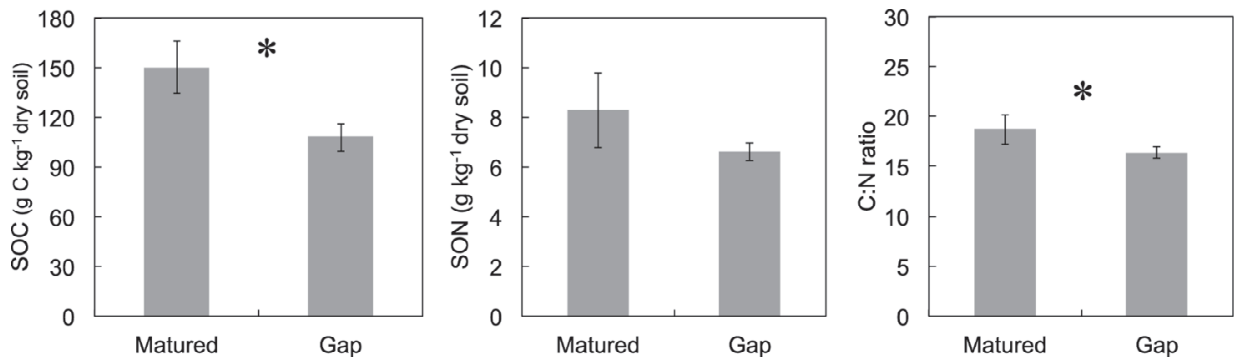

Fig. 3 Total carbon, nitrogen, and $\mathrm{C}: \mathrm{N}$ ratio of surface mineral horizons in the matured and gap areas. Asterisk indicates significant difference $(P<0.05)$.

Aromatic $\mathrm{C}=2.84 \times A_{600} / C+28.1, r=0.840$ $(P<0.005, n=18)$

Carboxyl C $=100-($ alkyl $\mathrm{C}+O$-alkyl $\mathrm{C}+$ Aromatic $\mathrm{C}), r=0.564(P<0.05, n=18)$

\section{Results and discussion}

\section{1) Aboveground detritus production}

The annual aboveground litter production from 2005 to 2011 in the matured and gap areas is shown in Table 3. The values of annual fine litter (foliage) production in the matured area were consistently higher than those of the gap area during the study period except for 2010. In particular, fine litter production in the matured area in 2011 was significantly higher than that of gap. On the other hand, annual coarse litter production showed a different trend with large variation in the both stands. Annual coarse litter production in cool-temperate deciduous broadleaved forests often varies more than fine litter production (Ohtsuka et al., 2007). Our annual litter production data were comparable with this trend. In addition, previous studies have reported that, in old-growth forests, the forest floor carbon (litter layer) was significantly lesser in canopy gap stands than in closed canopy stands (e.g., Fredeen et al., 2005; Scharenbroch and Bockheim, 2008). Therefore, in this study site, it could be expected that, compared to the gap area, stable and continuous higher annual litter production, especially fine litter production, may occur in the matured area for several to tens of years.

Generally, fine litter is easier to decompose and/ or humify than coarse litter in in situ conditions (Fogel and Cromack, 1977). In other words, fine litter is easier to incorporate into the mineral soil matrix as micro-scale debris and/or dissolved organic matter than coarse litter (Sollins et al., 1996). Therefore, aboveground fine litter production is probably one of the key factors that controls carbon accumulation in the surface mineral horizon of Japanese cool-temperate deciduous broad-leaved old-growth forests.

\section{2) Soil organic matter content}

Gravimetric soil carbon and nitrogen content, and $\mathrm{C}: \mathrm{N}$ ratios of surface mineral horizons in the matured and gap areas are shown in Fig. 3. The $\mathrm{C}$ values for the matured and gap areas 
were $150.1 \pm 15.7$ and $108.5 \pm 7.4 \mathrm{~g} \mathrm{C} \mathrm{kg}^{-1}$, respectively. In contrast, gravimetric soil nitrogen content was not significantly different. The potential capacity of organic matter incorporated or absorbed into the soil mineral matrix was probably not significantly different between the matured and gap areas in this study site. The amount of labile and active metals (especially $\mathrm{Al}$ and $\mathrm{Fe}$ ), which are primarily responsible for controlling the incorporation of organic matter into soil (Guggenberger and Zech, 1993; Kaiser and Guggenberger, 2000), was almost the same (data not shown). Therefore, compared to the gap area, higher carbon input or lower carbon output must occur in the matured area.

The annual fine litter production data described above supports this $\mathrm{C}$ balance theory. In addition, the $\mathrm{C}: \mathrm{N}$ ratios in the matured area were significantly higher than those of the gap area. The $\mathrm{C}: \mathrm{N}$ ratio of soil organic matter often declines during decomposition because organic $\mathrm{C}$ is oxidized by heterotrophic microbes, whereas $\mathrm{N}$ is relatively conserved in the microbial biomass due to microbial $\mathrm{N}$ demand (Wagai et al., 2009). Therefore, our $\mathrm{C}: \mathrm{N}$ ratio data suggested that soil organic matter in the gap area has been biodegraded more rapidly than those in the matured area. In situ surface carbon efflux was significantly greater in canopy gap stands compared to the closed canopy stands in subalpine old-growth forests (Scharenbroch and Bockheim, 2008). This also strongly supports our finding that $\mathrm{C}: \mathrm{N}$ ratios vary between the matured and gap areas.

\section{3) Chemical characteristics of soil organic matter}

Soil humic acids contents in the matured and gap areas were $75.0 \pm 7.8$ and $54.2 \pm 3.7 \mathrm{~g} \mathrm{C} \mathrm{kg}^{-1}$, respectively, indicating higher values than those of other SOC fractions (e.g., fulvic acids and humin). The degree of darkness $\left(A_{600} / C\right.$ values $)$ and the estimated composition of the $\mathrm{C}$ functional groups in soil humic acids in the matured and gap areas are shown in Fig. 4. The estimated compositions of carbonyl $\mathrm{C}$ and aromatic $\mathrm{C}$ in total $\mathrm{C}$ of soil humic acids in the matured area were significantly higher than their respective compositions in the gap area, and those of $O$-alkyl $\mathrm{C}$ and alkyl $\mathrm{C}$ in the matured area were significantly lower than those in the gap area. Generally, the chemical characteristics of aromatic $\mathrm{C}$ moieties in soil humic acids originate from polyphenol, which is primarily derived from lignin moieties (Stevenson, 1994). In addition, over a period of several years, lignin is more difficult to biodegrade than lowermolecular plant materials such as hemicellulose and cellulose (Berg and McClaugherty, 2004). Consequently, aromatic $\mathrm{C}$ moieties would be oxidized and/or synthesized and incorporated as humic acids into more recalcitrant materials (Stevenson, 1994). Therefore, the greater number of carbonyl $\mathrm{C}$ and aromatic $\mathrm{C}$ moieties in soil humic acids in a matured area than in a gap area may relate to the continuous higher annual fine litter production from aboveground. In addition, belowground litter production (including coarse woody debris) and carbon accumulation in mineral soil in the closed canopy stands might also be greater than those of the canopy gap stands (Gleixner et al., 2009) and may result in the higher carbonyl $\mathrm{C}$ and aromatic $\mathrm{C}$ composition of soil humic acids in the matured area as compared to the gap area.

The increase in the alkyl $\mathrm{C}$ to $O$-alkyl $\mathrm{C}$ ratio is commonly considered a result of preferential degradation of $O$-alkyl C (e.g., carbohydrate) and microbial synthesis of alkyl $\mathrm{C}$ (Baldock et $a l .$, 1989). The alkyl C:O-alkyl $\mathrm{C}$ ratios in the matured area were significantly lower than those of the gap area (Fig. 4). This result suggests that more easily decomposable materials such as a carbohydrate rather than aromatic $\mathrm{C}$ and alkyl $\mathrm{C}$ moieties tend to accumulate more in the matured area than in the gap area. In addition, these materials could be decomposed more easily in the gap area. Species composition in the matured and gap areas is not remarkably different (Table 2 ). Therefore, effects of the vegetation types on soil $\mathrm{C}$ dynamics between both areas are probably not so important in this study site. Canopy gap stands generally have soil moisture, soil temperature, and incoming solar radiation greater than those in the adjacent closed canopy stands (e.g., Collins and Pickett, 1987; Poulson and Platt, 

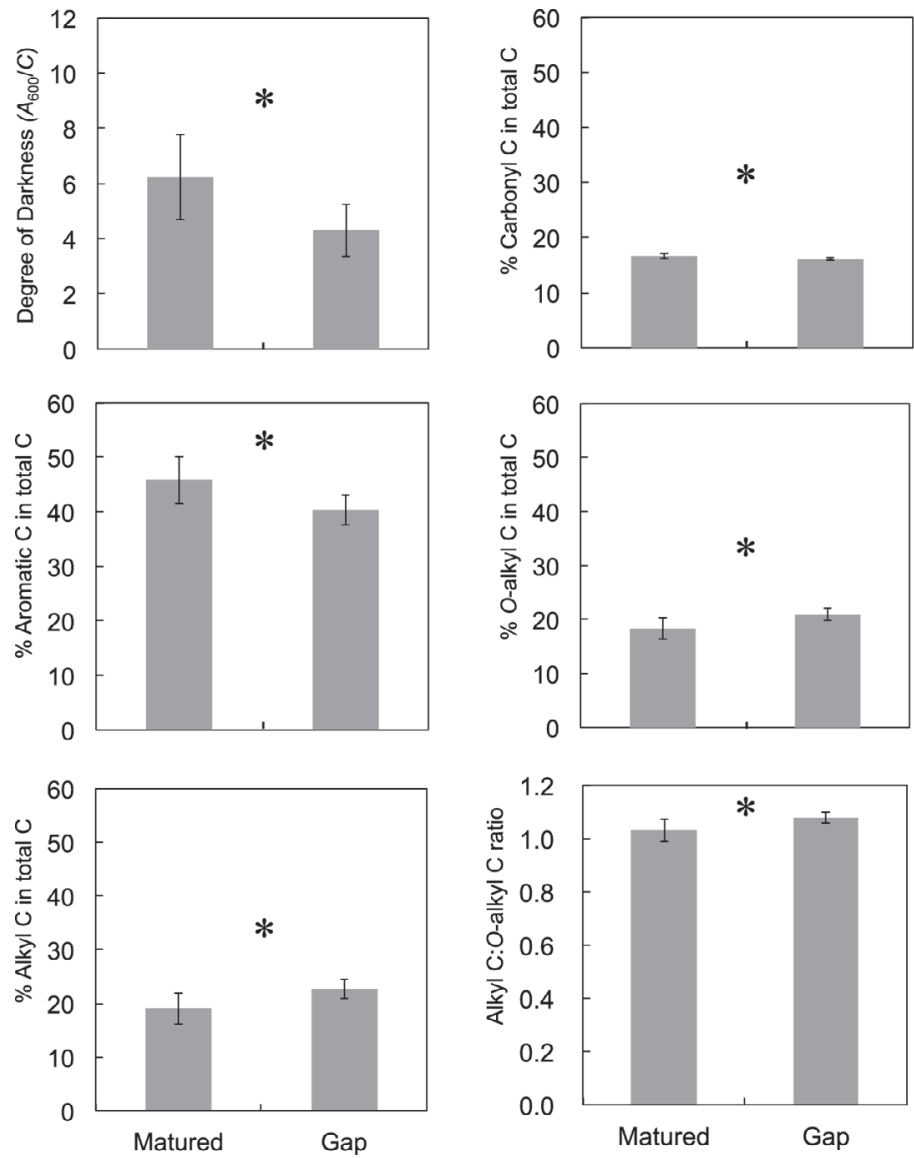

Fig. 4 Degree of darkness $\left(A_{600} / C\right)$ and estimated each carbon species of soil humic acids in the matured and gap areas. Asterisk indicates significant difference $(P<0.05)$.

1996; Scharenbroch and Bockheim, 2007). These factors significantly affect key soil decomposition processes such as organic matter decomposition, in particular, the decomposition of more labile organic carbon (Denslow et al., 1998). Therefore, soil microclimates may also significantly affect these differences of soil organic matter quality between the matured and gap areas in this study site.

\section{Conclusions}

This study demonstrated the importance of the closed canopy stands on aboveground litter production, surface soil organic matter content, and surface soil organic matter quality in a Japanese old-growth beech forest. Closed canopy stands showed higher aboveground litter production, higher soil organic carbon content, higher soil $\mathrm{C}: \mathrm{N}$ ratio, and lower alkyl $\mathrm{C}$ :O-alkyl $\mathrm{C}$ ratios on soil humic acids than those in the canopy gap stands. Our data strongly suggest that, compared to the canopy gap stands, closed canopy stands can be a carbon sink, which is strongly dependent on labile carbon dynamics.

\section{Acknowledgements}

We are grateful to Kazuko Iura and Kaichi Harada for their field assistance. This work is a part of the Ministry of the Environment's "Monitoring Sites 1000" Project. The study was supported by a Grant-in-Aid for Scientific Research from the Japan Society for the Promotion of Science and by a Japanese Alps InterUniversity cooperative Project (JALPS). 


\section{Notes}

1) SIN01.zip, downloaded from http://www.biodic. go.jp/moni1000/findings/data/index.html [Cited $2012 / 10 / 24]$.

2) http://www.humicsubstances.org [Cited 2012/10/24].

\section{References}

Baldock, J.A., Oades, J.M., Vassallo, A.M. and Wilson, M.A. (1989): Incorporation of uniformly labeled ${ }^{13} \mathrm{C}$ glucose into the organic fraction of a soil: Carbon balance and CPMAS ${ }^{13} \mathrm{C}$ measurements. Australian Journal of Soil Research, 27, 725-746.

Berg, B. and McClaugherty, C. (2004): Decomposition, Humus Formation, Carbon Sequestration. Springer, Japan (in Japanese).

Collins, B.S. and Pickett, S.T.A. (1987): Influence of canopy opening on the environment and herb layer in a northern hard-woods forest. Vegetation, 70, 3-10.

Denslow, J.S., Ellison, A.M. and Sanford, R.E. (1998): Treefall gap size effects on above-and below-ground processes in a tropical wet forest. Ecology, 86, 597609.

Fogel, R. and Cromack, K.J. (1977) : Effect of habitat and substrate quality on Douglas fir litter decomposition in western Oregon. Canadian Journal of Botany, 55, 1632-1640.

Fredeen, A.L., Bois, C.H., Janzen, D.T. and Sanborn, P.T. (2005): Comparison of coniferous forest carbon stocks between old-growth and young second-growth forests on two soil types in central British Columbia, Canada. Canadian Journal of Forest Research, 35, 1411-1421.

Frelich, L.E., Calcote, R.R. and Davis, M.B. (1993): Patch formation and maintenance in an old-growth hemlock hardwood forest. Ecology, 74, 55-68.

Gleixner, G., Tefs, C., Jordan, A., Hammer, M., Wirth, C., Nueske, A., Telz, A., Schmidt, U.E. and Clatzel, S. (2009): Soil carbon accumulation in old-growth forests. in Old-growth Forests edited by Wirth, C., Gleixner, G. and Heimann, M., Springer, Berlin, 231266.

Guggenberger, G. and Zech, W. (1993): Dissolved organic carbon control in acid forest soils of the Fichtelgebirge (Germany) as revealed by distribution patterns and structural composition analyses. Geoderma, 59, 109129

Ikeya, K. and Watanabe, A. (2003): Direct expression of an index for the degree of humification of humic acids using organic carbon concentration. Soil Science and Plant Nutrition, 49, 47-53.

Ikeya, K., Yamamoto, S. and Watanabe, A. (2004): Semiquantitative GC/MS analusis of thermochemolysis products of soil humic acids with various degrees of humification. Organic Geochemistry, 35, 538-594.

Ishihara, M.I., Suzuki, S.N., Nakamura, M., Enoki, T., Fujiwara, A., Hiura, T., Homma, K., Hoshino, D., Hoshizaki, K., Ida, H., Ishida, K., Itoh, A., Kaneko,
T., Kubota, K., Kuraji, K., Kuramoto, S., Makita, A., Masaki, T., Namikawa, K., Niiyama, K., Noguchi, M., Nomiya, H., Ohkubo, T., Saito, S., Sakai, T., Sakimoto, M., Sakio, H., Shibano, H., Sugita, H., Suzuki, M., Takashima, A., Tanaka, N., Tashiro, N., Tokuchi, N., Yakushima Forest Environment Conservation Center, Yoshida, T. and Yoshida, Y. (2011): Forest stand structure, composition, and dynamics in 34 sites over Japan. Ecological Research, 26, 1007-1008.

Kaiser, K. and Guggenberger, G. (2000): The role of DOM sorption to mineral surfaces in the preservation of organic matter in soils. Organic Geochemistry, 31, 711-725.

Luyssaert, S., Schulze, E.D., Börner, A., Knhl, A., Hessenmöller, D., Law, B.E., Ciais, P. and Grace, J. (2008): Old-growth forests as global carbon sinks. Nature, 455, 413-415.

Mao, J.D., Fang, X., Schmidt-Rohr, K., Carmo, A.M., Hundal, L.S. and Thompson, M.L. (2007): Molecularscale heterogeneity of humic acid in particle-size fractions of two lowa soils. Geoderma, 140, 17-29.

Messier, C., Posada, J., Aubin, I. and Beaudet, M. (2009): Functional relationships between old-growth forest canopies, understory light and vegetation dynamics. in Old-growth forests edited by Wirth, C., Gleixner, G. and Heimann, M., Springer, Berlin, 115-139.

Mladenoff, D.J. (1990): The relationship of the soil seed bank and understory vegetation in old-growth northern hardwood-hemlock treefall gaps. Canadian Journal of Botany, 68, 2714-2721.

Odum, E.P. (1969): The strategy of ecosystem development. Science, 164, 262-270.

Odum, E.P. (1985): Trends in stressed ecosystems. Bioscience, 35, 419-422.

Ohtsuka, T., Mo, W., Satomura, T., Inatomi, M. and Koizumi, H. (2007): Biometric based carbon flux measurements and net ecosystem production (NEP) in a temperate deciduous broad-leaved forest beneath a flux tower. Ecosystems, 10, 324-334.

Pastor, J. and Broschart, M. (1990): The spatial pattern of a northern conifer hardwood landscape. Landscape Ecology, 4, 55-68.

Poulson, T.L. and Platt, W.J. (1996): Replacement patterns of beech and sugar maple In; Warren Woods, Michigan. Ecology, 77, 535-576.

Pregitzer, K.S. and Euskirchen, E.S. (2004): Carbon cycling and storage in world forests: biome patterns related to forest age. Global Change Biology, 10, 20522077.

Riddoch, I., Lehto, T. and Grace, J. (1991): Photosynthesis of tropical tree seedlings in relation to light and nutrient supply. New Phytologist, 119, 137-147.

Scharenbroch, B.C. and Bockheim, J.G. (2007): Pedodiversity in an old growth northern hardwood forest in the Huron Mountains, Upper Peninsula, Michigan. Canadian Journal of Forest Research, 37, 1106-1117.

Scharenbroch, B.C. and Bockheim, J.G. (2008): Gaps 
and soil C dynamics in old growth northern hardwoodhemlock forests. Ecosystems, 11, 426-441.

Schlesinger, W.H. (1990): Evidence from chronosequence studies for a low carbon-storage potential of soils. Nature, 348, 232-234.

Smernik, R.J., Olk, D.C. and Mahieu, N. (2004): Quantitative solid-state ${ }^{13} \mathrm{C} \mathrm{NMR}$ spectroscopy of organic matter fractions in lowland rice soils. European Journal of Soil Science, 55, 367-379.

Sollins, P., Homann, P. and Caldwell, B.A. (1996): Stabilization and destabilization of soil organic matter: Mechanisms and controls. Geoderma, 74, 65-105.

Stevenson, F.J. (1994): Humus Chemistry, Genesis, Composition, Reactions, second ed. Wiley, New York.

Suchanek, T.H., Mooney, H.A., Franklin, J.F., Gucinski,
H. and Ustin, S.L. (2004): Carbon dynamics of an oldgrowth forest. Ecosystems, 7, 421-426.

Wagai, R., Mayer, L.M. and Kitayama, K. (2009): Nature of "occluded" low-density fraction in soil organic matter studies: A critical review. Soil Science and Plant Nutrition, 55, 13-25.

Watanabe, A. (2007): Isolation and purification of soil humic substances by IHSS method edited. in Handbook of Humic Substances Analysis edited by Watanabe, A., Fujitake, N. and Nagao, S., Sankei, Nagoya, 58-63. (in Japanese)

Wilson, M.A. (1987): NMR Techniques and Applications in Geochemistry and Soil Chemistry. Pergamon, Oxford. 


\title{
ブナ成熟林における成熟林エリアとギャップエリアの 土㙵有機炭素量および質の比較
}

\author{
飯 村 康夫* 廣 田 充** \\ 井田秀 行***大塚 俊 之*
}

冷温帯ブナ成熟林生態系において林冠構造の 違いによる表層土培有機炭素の量および質的特 性を比較した。1 ha の調査区内で典型的な成熟 林エリア $(n=7)$ およびギャップエリア $(n=$ 3）を選抜し(各 $400 \mathrm{~m}^{2}$ ), リター生産量, 土珡 有機物量，土壤フミン酸の質的特性を比較した。 2005 年から 2011 年までのリター生産量は全体 的に成熟林エリアで高い傾向が認められ，とくに 葉リターはつねに高い傾向を示した。土壌有機物 量は成熟林エリアで有意に多く, CN 比は高い值 を示した。土壤フミン酸の光学的特性から推定し た各種官能基炭素割合を比較したところ，成熟林
エリアでは芳香族炭素割合が高く, 炭水化物炭素 や脂肪族炭素割合は比較的低いことが推察され た。また, 微生物分解程度の目安となる脂肪族炭 素：炭水化物炭素比は成熟林エリアで比較的低い 結果が示された。成熟林エリアにおける土壌フミ ン酸の黒色度がそれほど高い值ではないことも合 わせて考察すると, 本研究サイトでは, 成熟林工 リアでより土壌有機炭素が蓄積しやすいと結論づ けられるが, 一方で, 分解ポテンシャルは比較的 高い土壤有機炭素が多く含まれていることも化学 構造特性や CN 比から示唆された。

キーワード : 林冠ギャップ, 炭素動態, 閉鎖林冠, 成熟林, 土壌有機物

\footnotetext{
* 岐阜大学流域圈科学研究センター

*** 筑波大学生命環境系

*** 信州大学教育学部附属志賀自然教育研究施設
} 